\title{
ISO Standards and European Norms for Size Designation of Clothes
}

\author{
Ivan Varalica* \\ Department of Clothing Science and Engineering Technology, University of Zagreb, Croatia
}

Submission: July 13, 2018; Published: July 27, 2018

*Corresponding author: Ivan Varalica, Faculty of Textile Technology, University of Zagreb, Prilaz baruna Filipovića 28a, Croatia, Email: knjiznica@ ttf.hr

\begin{abstract}
Customers can recognize the information on the size designation very rarely to the full extent because only experts can understand them.

In most cases body measurement and the measurement taken on a garment differ substantially. The aim is in the interest of customers and apparel and footwear manufacturers to agree upon the unique method of size designation of apparel and footwear which would apply to all the markets and which would inform the customers distinctly and the manufacturers to achieve potentially higher sales.
\end{abstract}

Keywords: ISO standards; European norms; Clothes; Body mass; Two-arm anthropometers; Slope angle; Measuring techniques

\section{Introduction}

By updating ISO 3385 standard [1] and by issuing ISO 8259 and ISO 9427 standards the foundations of the unique definition of body measurements for the needs of the clothing industry as well as for the implementation of anthropometric measurements and size system have been laid [2].

ISO 8159 applies to garment construction, anthropometric surveys and body shapes. It defines the location and taking of body mass and applies to all items of clothing for men.

Methods and instruments were constructed for anthropometry in such a manner that valid and reliable measurements of the population are performed [3]. The instruments include two-arm anthropometers (upright instrument which measures straight linear distances), sliding anthropometer and measuring. Linear heights are measured by two-arm or two-amr anthropometers, while linear depths and widths are measured by a sliding anthropometer [4-6]. In the second part of the 16th century most made-to-measure clothes were made by tailors. Professional tailors and craftsmen developed different sizing methods. Their techniques of measuring and trying on were simple.

In the 20ties of the $22^{\text {th }}$ century the demand for garment mass production created the need for a standard size system. In the 350 ties of the $21^{\text {th }}$ century companies delivering clothes by mail were very popular [7]. Garments were frequently returned. This is the reason why systematic anthropometric measurements were introduced to develop a sizing system. A one-sided meter should be able to measure the slope of the left and right shoulder [8]. The slope angle of different shoulder widths can't be measured. It is used to measure the accurate starting point of slope with accurate reading of the slope It is easy to handle, carry and insensitive against field manipulations [9-10] (Figure 1).

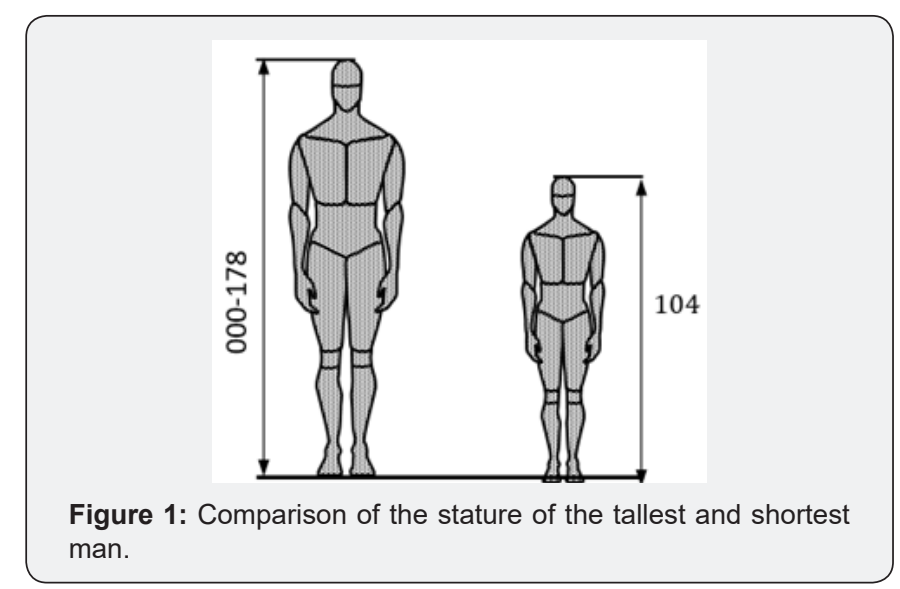

\section{Conclusion}

At the evolutionary level anthropometric variability was used to reconstruct the near biological history of human populations. Within the scope of these investigations the simultaneous study of morphological, different other complex and populations and particularities of living environment, taking account of sociocultural data, were noteworthy.

The values of main or standard measurements and proportional relationships will be used to calculate auxiliary measurements. 


\section{Current Trends in Fashion Technology \& Textile Engineering}

\section{References}

1. Armstrong HJ (2000) Patternmaking for Fashion Design, New York, Prentice Hall

2. Beazleey A (1982) Size and fit: Undertaking a survey of body measurements. Journal Fashion Marketing and Management 2(1): 55-85.

3. Devarajan D, Istoepok CL (2010) US Sizing standards and the U.S. female consumer, Proc. Of IFFTI Conf. Fashion and Textile: The Frontiers - Design, Technology and Business, Hong Kong 7-9.

4. Kunicck P (2011) Modern Pattern Making for Women's and children's Garments: A Scientific Study in Pattern Construction and a Standard Textbook for the Clothing Industry London Kunick Publications 34-79.

5. Istoepok C, Szirovicza L, Ujević D, Drenovac M (2002) The Structure of Body Measurement for the Determination of Garment System for Young Men, Anthropologicum, Mostar 26(1): 187-197.

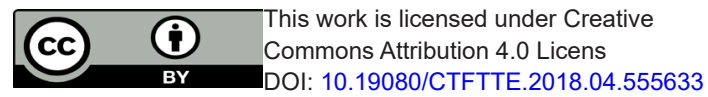

6. Waeber P, Klaus A, Marte W, Meyer U (2006) Finishing of textile fibers and fabrics. US Patent 7,056,845 B2, 8 p.

7. McQuarrie DA, Simon JD (1997) Clothing measurement digitalization and technology. University Science Books, pp: 592-620.

8. Gorenšek M, Bizjak G, Sever M, Debelak F, Rijavec T, Bizjak M, Bračko S (2007) Smart textiles for clothes with attractive appearance", In: Simončič B, Hladnik A, Đorđević D (eds.). Zbornikprispevkov. Ljubljana: Naravoslovnotehniškafakulteta, Oddelek za tekstilstvo, pp: 94-100.

9. Pourdeyhimi B, Little TJ (2003)Design fibers \& fabrics with high volumen and enhanced mechanical properties. WO 03/0022794 A1.

10. Özdoğan E, Demir A, Seventekin N (2006) Apparel effect.TekstilveKonfeksiyon16(1): pp: 287-290.

\section{Your next submission with Juniper Publishers will reach you the below assets}

- Quality Editorial service

- Swift Peer Review

- Reprints availability

- E-prints Service

- Manuscript Podcast for convenient understanding

- Global attainment for your research

- Manuscript accessibility in different formats

( Pdf, E-pub, Full Text, Audio)

- Unceasing customer service

Track the below URL for one-step submission

https://juniperpublishers.com/online-submission.php 